\title{
PENDEKATAN FENOMENOLOGI DALAM KOMUNIKASI ANTARAGAMA
}

\author{
Yuangga Kurnia $\boldsymbol{Y}$ \\ Sekolah Pascasarjana Universitas Gadjah Mada, Yogyakarta \\ yuangga4@gmail.com
}

\section{Abstract}

This paper will research the phenomenological approach in interfaith communication. The great development of communication media in this global era remains a classic problem of communication, that is an interfaith and interreligion communication. The strength globalization's flow which is destroying every borders between nations, regions and cultures, unfortunately, is not strong enough to destroy one solid wall, the border of religion and faith's differences. That problem becomes bigger and more complicated when the borders of religions and faiths create an unhealthy and unsmooth communication among people, as individual or communal. A lot of religious sentiments and communal violences based on religious view's differences and misunderstanding among faiths - which is happen from centuries ago - take place for the umpteenth time in many cities in Indonesia dan many countries in another hemisphere. Phenomenological approach is a theoretical perspective based on concept "back to the things themselves". In other words, this study is a structural consciousness that allows those consciousness to discover and understanding the objects outside of it. In Husserl's phenomenology, he made an epoche and eidetic vision as starting point of this perspective. Both of that concepts are a main and basic concept which is needed in interfaith communication to postponing judgement and looking with their own believer's perspective. This approach is radically needed to smooth out the interfaith communication. This approach also allows the transcultural communication and identity transformation from one religion's followers to another to reach a mutual agreement and decrease religious sentiments which are 
born from subjectivity of one religion's followers in judging another religions and their followers.

\section{Abstrak}

Makalah ini akan meneliti pendekatan fenomenologis dalam komunikasi antaragama. Perkembangan besar media komunikasi di era global ini tetap menjadi masalah klasike komunikasi, yaitu komunikasi antaragama dan antaragama. Kekuatan kekuatan arus globalisasi yang menghancurkan setiap perbatasan antara negara, wilayah, dan budaya, sayangnya, tidak cukup kuat untuk menghancurkan satu tembok kokoh, perbatasan agama dan perbedaan agama. Masalah itu menjadi lebih besar dan lebih rumit ketika perbatasan agama dan agama menciptakan komunikasi yang tidak sehat dan tidak mulus di antara orang-orang, sebagai individu atau komunal. Banyak sentimen keagamaan dan kekerasan komunal berdasarkan perbedaan pandangan agama dan kesalahpahaman di antara agama - yang terjadi sejak berabad-abad lalu terjadi untuk kesekian kalinya di banyak kota di Indonesia dan banyak negara di belahan bumi lain. Pendekatan fenomenologis adalah perspektif teoretis yang didasarkan pada konsep "kembali ke hal-hal itu sendiri". Dengan kata lain, penelitian ini adalah kesadaran struktural yang memungkinkan kesadaran itu untuk menemukan dan memahami objek di luarnya. Dalam fenomenologi Husserl, ia membuat visi epoche dan eidetik sebagai titik awal dari perspektif ini. Kedua konsep itu adalab konsep utama dan dasar yang diperlukan dalam komunikasi antaragama untuk menunda penilaian dan melihat dengan perspektif orang percaya mereka sendiri. Pendekatan ini sangat diperlukan untuk memperlancar komunikasi antaragama. Pendekatan ini juga memungkinkan komunikasi transkultural dan transformasi identitas dari pengikut satu agama ke agama lain untuk mencapai kesepakatan bersama dan mengurangi sentimen agama yang labir dari subyektivitas pengikut satu agama dalam menilai agama lain dan pengikut mereka.

Keywords: Phenomenology, epoche, interfaith communication, cross-cultural communication

\section{A. Pendahuluan}

Tahun 2018 ditandai dengan pelaporan dua orang stand-up comedian Indonesia dengan tuduhan melecehkan dan menistakan agama Islam. Kedua stand-up comedian tersebut diduga melakukan pelecehan dan penistaan agama saat tengah open mic. Materi jokes yang 
dilemparkan kedua stand-up comedian tersebut dianggap melecehkan agama Islam dan berbuntut penuntutan dan pelaporan ke pihak yang berwajib ${ }^{1}$. Mereka berdua dijerat dengan pasal 156 huruf a KUHP tentang penistaan agama oleh seorang tokoh dari Forum Umat Islam Bersatu atau FUIB. Selain itu, di dunia maya beredar tagar \#BoikotGePamungkas dan \#TangkapGedanJoshua digunakan sebanyak 13.000 dan 23.000 cuitan sejak Senin Malam (8/1) hingga Selasa malam $(9 / 1){ }^{2}$

Kasus dugaan penistaan agama yang dilakukan oleh pemeluk agama lain bukanlah hal baru di Indonesia. Salah satu kasus terheboh adalah dugaan penistaan agama Islam oleh mantan Gubernur DKI Jakarta, Basuki Tjahaja Purnama atau Ahok pada 2016. Kasus tersebut memicu demo umat Islam dalam skala besar yang disebut "Aksi Bela Islam 212" untuk menuntut pemenjaraan Ahok. Selain itu, beberapa kasus terkait juga terjadi dalam 8 tahun terakhir. Pada 2010, Pendeta Antonius Rechmon Bawengan dituntut atas dugaan penistaan agama Islam dengan penyebaran dua buku berjudul "Ya Tuhan Tertipu Aku" dan "Saudara Perlukan Sponsor". Pendeta tersebut harus menerima hukuman penjara selama 5 tahun. Pada 2013, seorang wanita beragama Kristen di Bali harus menerima hukuman penjara selama 14 bulan karena menghina agama Hindu. Ia dilaporkan ke pihak berwajib setelah menyebut persembahan Hindu "kotor dan menjiiikan".

Pada 2017, Ketua Umum Front Pembela Islam (FPI), Habib Rizieq Shihab juga harus berurusan dengan kepolisian terkait tuduhan serupa. Ia dituduh telah menistakan konsep ketuhanan agama Kristen dengan mempertanyakan "Siapa bidan yang membantu kelahiran Tuhan Yesus?". Perkataan tersebut muncul dalam ceramahnya di Pondok Kelapa Jakarta Timur pada 25 Desember 2016 ${ }^{5}$. Pada tahun yang sama, Eggi Sudjana, seorang aktivis dan juga tokoh alumni 212 dilaporkan oleh ketua DPN Perhimpunan Pemuda Hindu Indonesia (Peradah) dan Ketua Umum Perjuangan Umum Rakyat Nusantara kepada Bareskrim Polri atas tuduhan serupa. Ia mengatakan bahwa

\footnotetext{
${ }^{1}$ Dalam CNN Indonesia, 9/1/2018

2 Dalam BBC.com, 9/1/2018

${ }^{3}$ Dalam Globalmuslim, 2/2011

${ }^{4}$ Dalam bekasimedia, 11/10/2016

${ }^{5}$ Dalam Merdeka.com, 16/1/2017
} 
konsep ketuhanan pemeluk agama selain Islam bertentangan dengan konsep "Ketuhanan Yang Maha Esa" dalam Pancasila.

Berbagai kasus serupa juga cukup banyak terjadi di Indonesia. Indonesia yang telah merdeka selama 72 tahun adalah sebuah negara dan bangsa yang plural dan multikultural. Berbagai dugaan penistaan dan pelecehan agama oleh pemeluk agama lainnya merupakan sebuah hal yang sepatutnya tidak terjadi. Berbagai ujaran dan pernyataan yang melecehkan pemeluk agama lain merupakan hasil dari kurang harmonisnya kerukunan yang terbangun antar pemeluk agama di Indonesia. Bila dibiarkan, dugaan dan pelecehan serupa dapat memicu kekerasan komunal antar umat beragama. Adapun yang menjadi salah satu penyebab ketidakharmonisan tersebut adalah adanya kecurigaan dan prasangka yang dilabelkan oleh satu pemeluk agama kepada pemeluk agama lainnya. Kecurigaan dan prasangka inilah yang menyebabkan sulitnya terjalin komunikasi dan interaksi yang sehat antar pemeluk agama di Indonesia.

Perbincangan tentang agama atau kepercayaan memang tidak akan pernah selesai, seiring dengan perkembangan masyarakat itu sendiri. Baik secara teologis maupun sosiologis, agama atau kepercayaan dapat dipandang sebagai instrument untuk memahami dunia. Dalam konteks itu, hampir-hampir tak ada kesulitan bagi agama apapun untuk menerima premis tersebut. Secara teologis, hal itu dikarenakan oleh watak omnipresent agama. Yaitu, agama, baik melalui simbol-simbol atau nilai-nilai yang dikandungnya "hadir di mana-mana", ikut mempengaruhi, bahkan membentuk struktur sosial, budaya, ekonomi dan politik serta kebijakan publik.

Satu kelompok pemeluk agama atau kepercayaan sering menilai dan memahami konsep serta ajaran agama lain melalui sudut pandang agama mereka. Sudut pandang eksklusivisme dan inklusivisme ini terbukti menimbulkan berbagai ketegangan sejak berabad-abad lalu. Klaim kebenaran oleh satu pihak dan kesalahan di pihak-pihak lainnya membuat pihak yang "merasa" benar dapat bebas

${ }^{6}$ Dalam Tribunnews, 19/10/2017

${ }^{7}$ Kiki Muhamad Hakiki, Politik Identitas Agama Lokal (Studi Kasus Aliran Kebatinan), Analisis, Volume XI, Nomor 1, Juni 2011, h. 160. 
menafsirkan konsep agama pihak lainnya dan menghakimi mereka dengan sudut pandang agamanya.

Salah satu solusi untuk meminimalisir kecurigaan, prasangka buruk hingga penodaan agama lain adalah dengan membina komunikasi yang baik antar pemeluk agama. Suatu komunikasi juga tidak dapat berjalan mulus bila masing-masing pihak (komunikan dan komunikator) berpandangan ekslusif dan inklusif dalam memandang agama lain. Pendekatan fenomenologi yang terkenal dengan konsep epoche dan eidetic vision memberikan tawaran untuk memulai pemahaman konsep agama lain menurut yang mereka yakini, bukan dari perspektif dan prasangka dari agama lain. Dengan demikian, diharapkan antar pemeluk agama mengetahui dan memahami mana "Yang Sakral" dan mana "Yang Profan" bagi pemeluk suatu agama. Mana yang dapat dijadikan perbincangan dan mana yang tidak perlu disinggung.

Artikel ini akan membahas bentuk komunikasi agama berlandaskan komunikasi antarbudaya. Selanjutnya akan dipaparkan secara singkat tentang konsep fenomenologi dalam memahami agama dan model teologi antaragama. Artikel ini akan ditutup dengan pengaplikasian pendekatan fenomenologi dalam komunikasi antaragama dalam konteks Indonesia. Artikel ini menggunakan sumber data pustaka dan dokumen-dokumen media sebagai sumber pendukung.

\section{B. Model Komunikasi Antar Budaya}

Agama adalah salah satu dari tujuh unsur budaya menurut Koentjaraningrat. Selain agama atau sistem kepercayaan, budaya juga tersusun atas unsur bahasa, sistem pengetahuan, sistem pencaharian, sistem teknologi, sistem organisasi masyarakat dan seni ${ }^{8}$. Dalam membahas bentuk komunikasi antar agama dan sistem kepercayaan tidak dapat tanpa melibatkan cangkupan yang lebih luas dari agama dan sistem kepercayaan itu sendiri, yaitu budaya. Budaya yang dikenal pula dalam bahasa Arab sebagai "Tsaqaafab" adalah kunci untuk melahirkan suatu peradaban (chadhaarah). Suatu peradaban tidak akan

8 Yuangga KurniaYahya, Upaya Bahasa Arab Dalam Menghadapi Era Globalisasi, (Malang: UM Press, 2017), h. 38 
muncul tanpa didasari oleh kebudayaan dan kemajuan intelektual ${ }^{9}$. Will Durant, ahli sejarah dari Amerika memberikan definisi peradaban sebagai sebuah tata kehidupan sosial yang menuntut masyarakatnya untuk menjaga dan mengembangkan produk budaya mereka $^{10}$. Dari definisi tersebut dapat dipahami bahwa budaya merupakan embrio dari suatu peradaban.

Menurut Kamus Besar Bahasa Indonesia (KBBI), kebudayaan adalah hasil kegiatan dan penciptaan (akal budi) manusia. Adapun dalam Oxford Living Dictionaries, budaya (culture) adalah seni dan berbagai manifestasi lain dari hasil intelektual manusia yang terjadi secara kolektif atau ide-ide, kebiasaan dan perilaku sosial dari suatu masyarakat. Kebudayaan manusia lahir dan berkembang dengan berbagai perbedaan antara satu dan yang lainnya. Sebuah tindakan yang tidak bijak bila menyamaratakan semua budaya manusia karena perbedaan antara budaya tersebut adalah sebuah keniscayaan. Perbedaan bahasa, pola pikir, kondisi ekonomi hingga kondisi alam adalah sedikit hal yang mensyaratkan adanya perbedaan budaya satu dan yang lainnya. Namun satu hal yang perlu dipahami bahwa semuanya mendukung terciptanya sebuah peradaban manusia yang utuh ${ }^{11}$. Perbedaan intelektual, estetika dan sosiologis tidak hanya terjadi antara ras dan golongan yang berbeda. Dua kebudayaan dapat lahir dari satu golongan atau ras yang sama dan memiliki sifat yang sama sekali berbeda. Maka tidak mengherankan bilamana dua budaya yang bertemu berasal dari asal-usul yang sama sekali berbeda akan bertolak belakang ${ }^{12}$.

Sistem budaya manusia akan berkembang sesuai dengan perubahan waktu, kondisi geografi dan lingkungan di mana mereka tinggal. Satu hal yang pasti adalah predikat manusia sebagai makhluk sosial tidak dapat dilepaskan. Ketika suatu sistem dalam sebuah kebudayaan akan terpisah atau terpecah, mereka akan membentuk aliansi-aliansi baru meski hanya terdiri dari sekelompok kecil manusia

9 Abu Zayd Syalby, Taariikhu'l Chadhaarah al-Islaamiyyah wa'l Fikru'l Islaamy (Kairo: Maktabah Wahbah, 2012), h. 7

${ }^{10} \mathrm{Ibid}$, h. 8

${ }^{11}$ Claude Levi Strauss, Race and History, (Paris: Unesco, 1952), h. 6-8

12 Ibid, h. 6 
atau yang disebut sebagai "The Alliance Theory"13. Karenanya, tidak mengherankan bila Levi Strauss menyebutkan bahwa jumlah kebudayaan manusia lebih besar bila dibandingkan jumlah ras manusia ${ }^{14}$. Arti penting budaya bagi manusia (kelompok manusia) antara lain sebagai pemberi identitas (identity meaning), penyamaan ide (group inclusion), penetapan peraturan yang berbeda dengan kelompok lain (intergroup boundary regulation), adaptasi terhadap faktor ekologi (ecological adaptation) dan sarana untuk saling berkomunikasi (cultural communication). ${ }^{15}$

Persinggungan antar budaya adalah sebuah keniscayaan lain. Dengan perkembangan populasi umat manusia yang cepat dan kemajuan ilmu pengetahuan dan teknologi, mustahil sebuah budaya dapat hidup sendiri tanpa bersinggungan dengan budaya lainnya. Dr. Shrimati Das, dosen Department of English di Nehru Degree College, India menyebutkan bahwa keragaman adalah suatu keharusan dalam menjaga eksistensi suatu masyarakat dan budaya mereka. Sebuah kesalahan fatal bila bersikeras membangun suatu masyarakat yang "mono-culture" ". Levi Strauss menyebutnya sebagai sebuah koalisi yang terbentuk oleh kegiatan perdagangan, migrasi, peminjaman dan peperangan $^{17}$.

Pendapat tersebut senada dengan teori Samuel P Huntington yang disebut sebagai "Clash of Civilizations" 'benturan antarperadaban'. Benturan ini diakibatkan oleh beberapa faktor. Pertama, perbedaan antara satu peradaban lain adalah sesuatu yang nyata dan mendasar. Perbedaan ini menonjol dalam berbagai segi seperti segi historis, bahasa, adat istiadat, tradisi dan yang terpenting adalah agama dan sistem kepercayaan. Perbedaan ini merupakan sebuah produk yang telah tercipta sejak berabad-abad lalu (product of centuries) dan tidak dapat dihilangkan. Kedua, bumi telah menjadi tempat yang lebih sempit bagi manusia dibandingkan berabad-abad lalu. Pertumbuhan

13 Ibid, h. 10 dan Alan Jenkins, The Social Theory of Claude Levi-Strauss, (London: The Macmillan Press Ltd, 1979), h. 45

${ }^{14}$ Claude Levi Strauss, Race, h. 6

15 Stella Ting-Toomey, Communicating Across Cultures, (New York: The Guilford Press, 1999), h. 12-14

16 Shrimati Das, Culture as Competing Forces of Globalization, in International Seminar held by Intercultural Department, Faculty of Cultural Science, Gadjah Mada University of Yogyakarta, on October 23, 2017 (private document)

${ }^{17}$ Claude Levi Strauss, Race, h. 41 
manusia, perpindahan, peperangan dan bencana alam telah membuat dunia semakin sempit dan sulit untuk menghindari gesekan dengan peradaban lain. Ketiga, perubahan kehidupan sosial dan medernisasi ekonomi juga membuat seseorang sulit untuk berdiam dalam waktu yang lama pada satu identitas lokal.

Keempat, kesadaran akan perkembangan peradaban yang didorong dengan kemajuan peradaban Barat. Kelima, karakteristik antarbudaya dan perbedaan di dalamnya lebih sulit menyatu bila dibandingkan karaktertistik yang muncul dengan alasan politik dan ekonomi ${ }^{18}$. Benturan antar peradaban tesebut mau tidak mau berdampak pula pada benturan antarbudaya dan unsur-unsurnya yang merupakan asal lahirnya peradaban, termasuk dalam hal agama. Benturan tersebut semakin terasa di era modern ini, sebuah era yang ditandai dengan perkembangan pesat ilmu pengetahuan, teknologi, komunikasi, informasi hingga sistem kehidupan antarbudaya tanpa sekat (without any borders) ${ }^{19}$.

Kepekaan serupa juga dirasakan oleh Stella Ting-Toomey, professor dalam komunikasi ucapan (Speech Communication) di California State University. Ia menyadari bahwa memasuki abad XXI, perubahan dalam ekonomi global, teknologi, transportasi dan migrasi terjadi sangat cepat. Hal-hal tersebut yang membuat dunia ini terasa sempit. Dalam interaksi sosial, manusia saat ini akan dihadapkan pada situasi di mana ia harus berinteraksi dengan manusia lainnya dengan latar belakang budaya yang berbeda setiap harinya dan di mana pun ia berada, di ruang kerja, di kendaraan umum, di ruang kelas, di pasar dan di lingkungan tempat ia tinggal. Tanpa komunikasi antarbudaya yang baik, kehidupan di era ini akan menghadirkan kesulitan tersendiri. Ia menegaskan setidaknya ada tiga alasan dasar mengapa manusia zaman ini perlu mempelajari komunikasi antarbudaya. Pertama, adanya tren keragaman global. Kedua, tren keragaman domestik. Ketiga, semakin terbukanya kesempatan untuk mempelajari hubungan inter-personal. ${ }^{20}$

18 Samuel P Huntington, The Clash of Civilizations?, (New York: Foreign Affairs, Summer 1993. Vol. 72, Iss: 3;), h. 22-28

${ }^{19}$ Yuangga Kurnia Yahya, Upaya Bahasa Arab, h. 41

20 Stella Ting-Toomey, Communicating..., 3-4 dan Young Yun Kim, Communication and Cross-Cultural Adaptation: An Integrative Theory Intercommunication, (Clevedon: Multilingual Matters, Ltd, 1988), h. 3 
Keragaman global merupakan sebuah tren yang terjadi saat ini dan tidak dapat dihindari. Ia dapat menjadi sebuah kesempatan, namun di sisi lain juga menghadirkan tantangan baru. Pasar ekonomi bebas seolah meruntuhkan batas-batas budaya dalam melaksanakan transaksi global. Sebuah bisnis yang sukses adalah bisnis yang mampu bersaing di tingkat global. Di tingkat domestik juga terdapat keragaman lain. Di Amerika Serikat contohnya, penduduk asli Amerika hanya tersisa sedikit. Kuatnya arus migrasi pekerja dari Asia, Amerika Latin, Afrika dan minoritas lainnya menjadi penyebab hal tersebut. Migrasi para pendatang ke Amerika Serikat dan pertumbuhan mereka yang cepat disertai dengan membawa budayabudaya asal mereka. Hal ini menyebabkan Amerika Serikat menjadi melting pot bagi banyak budaya setelah sebelumnya banyak mengadopsi budaya imigran Eropa ${ }^{21}$.

Komunikasi yang baik antarbudaya sangat diperlukan demi menjaga keharmonisan dan menghargai keragaman yang ada. Komunikasi ini juga bermanfaat untuk meminimalisir (bila tidak dapat menghilangkan) perselisihan antara "kami" ("us") dan "mereka" ("them"/"the other") 22. Tanpa ada komunikasi yang baik, benturan antarbudaya akan menimbulkan dampak yang negatif, baik secara sosiologis maupun psikologis. Secara sosiologis, di level mikro kelompok-kelompok yang saling berdekatan akan berlomba-lomba dalam menguasai suatu kawasan, baik secara ekonomi, pengaruh atau hal lainnya. Perlombaan tersebut terkadang juga melegalkan kekerasan. Di level makro, negara-negara dari latar belakang peradaban dan budaya yang berbeda akan bersaing dalam merebut kekuatan militer dan ekonomi global, menguasai institusi internasional dan mempromosikan afiliasi politik dan keagamaan mereka masing-masing ${ }^{23}$. Secara psikologis, benturan ini dapat menyebabkan "culture shock" karena bertemu dengan budaya yang berbeda dengan yang ia ketahui. Reaksi dari "culture shock" tersebut beragam. Dapat berupa penolakan secara ideologis, hingga penolakan

21 Stella Ting-Toomey, Communicating..., 6 dan Ida Rohani, Culture as Competing Forces of Globalization, in International Seminar held by Intercultural Department, Faculty of Cultural Science, Gadjah Mada University of Yogyakarta, on October 23, 2017 (private document)

22 Samuel P Huntington, The Clash of, h. 24; Young Yun Kim, Communication and, h. 124 dan Yuangga Kurnia Yahya, Agama dan, h. 26

23 Samuel P Huntington, The Clash of, h. 24 
dengan jalan anarkis ${ }^{24}$. Bentuk lainnya adalah stress sebagai bentuk pertahanan diri dari budaya asing. Bila beruntung, fase stress dapat meningkat menjadi fase adaptasi dan pertumbuhan. Bila tidak, akan terjadi krisis yang merugikan kedua komunitas budaya ${ }^{25}$.

Komunikasi antarbudaya menurut Stella Ting-Toomey adalah proses pertukaran simbolik antar individual yang berasal dari dua (atau lebih) individu yang berasal dari komunitas budaya yang berbeda dan saling berbagi dan bernegosiasi tentang makna-makna yang dipahami dalam situasi yang interaktif ${ }^{26}$. Karakteristik utama dari model komunikasi ini adalah adanya pertukaran simbolik, proses, komunitas budaya yang berbeda, negosiasi atas makna-makna yang dibagikan (shared meanings) dan situasi yang interaktif. Untuk memperjelas bentuk komunikasi antar budaya, Stella Ting-Toomey memaparkan 5 asumsi dasar dalam prosesnya, yaitu:

1. Komunikasi antarbudaya melibatkan perbedaan derajat dari anggota suatu kelompok budaya.

2. Komunikasi antarbudaya mengakibatkan proses encoding dan decoding pesan, baik verbal maupun non-verbal yang serentak dan sama dalam proses pertukaran pesan.

3. Banyak perjumpaan antarbudaya akan mengakibatkan timbulnya "benturan" dalam arti baik.

4. Komunikasi antarbudaya erat terjadi dalam hal konteks.

5. Komunikasi antarbudaya terjadi dalam sistem yang telah tertanam dalam masyarakat ${ }^{27}$.

Dalam praktiknya, Stella Ting-Toomey secara lebih rinci menjabarkan proses komunikasi ini. Komunikasi ini dimulai dengan pengenalan baik dari perspektif kedua belah pihak terhadap identitas masing-masing. Hal tersebut dilanjutkan dengan perjumpaan nilainilai dan orientasi antarbudaya, dan komunikasi verbal dan nonverbal. Dalam tahap ini, kontak antar identitas kebudayaan yang berbeda akan banyak terjadi dan menghasilkan manajemen konflik yang baik antar kedua belah pihak. Puncak dari komunikasi ini adalah

\footnotetext{
24 Young Yun Kim, Communication and, h. 23

${ }^{25}$ Ibid, h. 114-115

26 Stella Ting-Toomey, Communicating, h. 16-17

${ }^{27}$ Stella Ting-Toomey, Communicating, h. 22-23
} 
kemampuan beradaptasi antabudaya dan transformasi identitas dan kompetensi antar komunitas budaya ${ }^{28}$.

Di akhir pemaparannya, Stella Ting-Toomey memberikan catatan penting bagi siapa pun yang akan menggeluti komunikasi antarbudaya, termasuk di dalamnya adalah komunikasi antaragama. Para penggiat komunikasi antar budaya harus memperhatikan hal-hal berikut:

1. Menghormati kelompok dan orang-orang dari budaya yang berbeda dengan dasar keadilan dan persamaan.

2. Bersiap dan bersedia untuk menjalani proses belajar seumur hidup dan menambah pengetahuan yang berkaitan dengan komunikasi budaya secara spesifik dan universal.

3. Selalu siap untuk mengambil keputusan secara sadar dalam menghadapi berbagai kemungkinan dalam praktik problemproblem kebudayaan.

4. Selalu berpegang pada komitmen sosial untuk menuju perubahan yang penuh kesadaran demi terciptanya masyarakat yang inklusif secara moral.

5. Berkomitmen untuk menjunjung tinggi martabat manusia dengan pola pikir yang penuh penghormatan (respectful mindset), hati yang lapang dan terbuka, visi yang inklusif melalui lensa dan perspektif berbagai budaya dan mempraktekkan kompetensi komunikasi trans-budaya yang didasari dengan kesadaran penuh ${ }^{29}$.

Teori komunikasi antarbudaya yang ditawarkan oleh Stella Ting-Toomey menjadi salah satu prinsip dalam menjalin komunikasi antaragama. Pendekatan yang ditawarkan untuk memulai langkah awal dalam komunikasi ini adalah pendekatan fenomenologi sebagai dasar untuk memahami pertukaran simbolik dan proses encodingdecoding yang terjadi antar pemeluk agama serta meminimalisir adanya gangguan (noise) dalam proses tersebut.

\footnotetext{
28 Ibid, h. viii-ix

29 Stella Ting-Toomey, Communicating, h. 276
} 


\section{Konsep Teologi Antaragama}

Dalam berbicara komunikasi dan perjumpaan antaragama harus berbicara dengan konsep teologi antaragama. Konsep teologi ini merupakan konsep dan model teologi yang terjalin antara satu agama dan agama lainnya. Konsep teologi antaragama yang banyak digunakan adalah Tipologi Tripolar yang digagas oleh Alan Race. Tipologi tripolar Alan Race mencakup tiga sikap dalam hubungan antaragama, yaitu eksklusivisme, inklusivisme dan pluralisme ${ }^{30}$. Ketiga konsep yang menjadi orientasi besar dalam wacana hubungan antaragama ini memang lahir dari pandangan agama Kristen terhadap agama lainnya kala itu. Namun konsep tersebut saat ini banyak diadopsi ke dalam hubungan berbagai agama di dunia.

Sikap yang pertama adalah eksklusivisme. Sikap ini merupakan sikap dan orientasi yang ingin membangun sebuah tempat tertutup atau dalam bahasa Ihsan Ali Fauzi sebagai kantong tertutup (enclave builder) yang menegaskan bahwa hanya ada satu keyakinan dan agama yang akan membawa keselamatan bagi manusia (the salvation of man) dan hanya ada satu cara untuk memahami realitas dan penafsiran dari yang suci ${ }^{31}$. Sikap ini memiliki muatan teologis yang kental dengan sangkaan buruk terhadap semua keyakinan yang berbeda dengan yang mereka yakini, baik perbedaan aliran dalam satu agama maupun perbedaan agama dan sistem keyakinan. Sikap "oneness" dan "onlyness" menjadi bahasa identitas dari sikap ini. Mereka juga berpegang teguh pada "no other name"

Sikap ini sering mengundang gesekan hingga benturan dengan penganut agama lainnya, khususnya mereka yang juga bersikap senada. Sejarah dari lahirnya pandangan ini adalah adanya doktrin Extra Ecclesiam Nulla Sallus'tidak ada keselamatan di luar gereja' dalam agama Kristen ${ }^{33}$. Namun sikap ini tidak berhenti di

30 Yuangga Kurnia Yahya, Agama dan Masyarakat, (Jakarta: nulisbuku.com self-publishing, 2017b), h. 118

${ }^{31}$ H. Nur Solikin, AR., Agama dan Problem Mondial, (Yogyakarta: Pustaka Pelajar, 2013), h. 104 dan Ihsan Ali Fauzi,, ed., Ketika Agama Bawa Damai, Bukan Perang: Belajar dari 'Imam dan Pastor", (Jakarta: PUSAD Paramadina, 2017), h. 5

32 Roger Boase, ed., Islam and Global Dialogue: Religious Pluralism and the Pursuit of Peace, (Hants, England: Ashgate Publishing Ltd, 2005), h. 25 dan h. 27

${ }^{33}$ Yuangga Kurnia Yahya, Agama dan, h. 23 dan Nur Solikin, Agama dan, h. 105 
Kristen saja dan muncul di berbagai penganut agama lainnya. Sebuah konsepsi wajar dari sebuah agama untuk memiliki klaim kebenaran (truth claim) dan klaim keselamatan (salvation), khususnya bagi agama yang meyakini konsep eskatologi. Masalah muncul ketika klaim yang harusnya berada di tataran teologis tersebut dipaksa masuk ke dalam ranah sosiologis ${ }^{34}$. Sikap inilah yang melahirkan pandangan "agama lain adalah jalan yang salah yang membawa pengikutnya kepada kesesatan" "35atau "kami diselamatkan dan anda dihukum" dan "pemeluk agama lain adalah penyembah berhala dan Tuhan agamaagama lain adalah berhala" 36 .

Sikap yang kedua adalah inklusivisme. Sikap ini merupakan sikap yang sedikit lebih "lunak" dari sikap yang pertama. Sikap ini mengakui adanya tradisi-tradisi dan kepercayaan-kepercayaan lain di luar kepercayaan yang diyakini, meskipun mengakui keunggulan suatu tradisi keagamaan dibanding yang lainnya ${ }^{37}$. James A Keaten mendefinisikan sikap ini sebagai suatu sikap dalam memahami agama dan kepercayaan komunitas lain dengan menggunakan sudut pandang dan ideologi agama yang dianut ${ }^{38}$. Karenanya, ia menyebut sikap ini sebagai "theological reductionism" 'reduksionisme teologi' yaitu mereduksi sikap teologi yang terlalu keras.

Dalam menjelaskan sikap ini, Alan Race mengacu pada konsep ketuhanan Kristus. Dalam teologi Kristen kala itu, terdapat pengakuan akan agama dan kepercayaan lain beserta kebenaran yang dibawanya. Namun agama yang dibawa Kristus dianggap agama yang terakhir dan penyempurna dari agama-agama yang terdahulu. Semua kebenaran agama-agama terdahulu telah terangkum dalam agama terakhir yang paripurna ${ }^{39}$.

${ }^{34}$ Yuangga Kurnia Yahya, Agama dan, h. 119-120

35 Nur Solikin, Agama dan, h. 104

${ }^{36}$ Nurcholis Madjid, Pluralitas Agama Kerukunan dalam Keragaman, Jakarta: Penerbit Kompas, 2001), h. 81 dan Harold Coward, Pluralisme Tantangan bagi Agama-Agama. Terj. Pluralism, Challenge to Worlds Religion, (Yogyakarta: Kanisius, 1989), h. 62 dan Yuangga Kurnia Yahya, Agama dan , h. 26-27

37 Ihsan Ali Fauzi, Ketika Agama, h. 5

38 James A Keaten dan Charles Soukup, Dialogue and Religious Otherness: Toward a Model of Pluralistic Interfaith Dialogue, (Artikel dalam Journal of International and Intercultural Communication, Vol. 2: No. 2, 2009), h. 168-187

39 Yuangga Kurnia Yahya, Agama dan, h. 119 
Sikap yang ketiga adalah pluralisme. Pluralisme adalah sikap dan orientasi yang menegaskan bahwa kebenaran dan ketepatan penafsiran hal yang suci bukan hak eksklusif suatu tradisi atau komunitas keagamaan tertentu ${ }^{40}$. Pluralisme didefinisikan oleh Josh McDowell sebagai "respecting others beliefs and practices without sharing them" "menghormati keimanan dan praktik ibadah pihak lain tanpa ikut serta (sharing) bersama mereka". Definisi tersebut disebut pula sebagai negative tolerance. Adapun pluralisme dalam artian positive tolerance adalah "every single individual's beliefs, values, lifestyle and truth claims are equal' 'setiap keimanan, nilai, gaya hidup dan klaim kebenaran dari setiap individu adalah sama ${ }^{41}$.

Pluralisme adalah mentolerir keberadaan dan eksistensi dari keragaman yang ada. Definisi tersebut sesuatu dengan yang tertuang dalam The Oxford English Dictionary, yaitu keberadaan toleransi keragaman kelompok-kelompok etnis dan budaya dalam suatu masyarakat atau negara, keragaman kepercayaan atau sikap yang ada pada sebuah badan atau institusi dan sebagainya ${ }^{42}$.

Namun paham ini sering disalahpahami sebagai suatu sikap yang menerima bahwa seluruh agama adalah benar dan sama. Paham pluralisme tersebut berdasar pada teori "Kesatuan Transenden Agama" Frithjof Schuon dan "Teologi Global" John Hick ${ }^{43}$. Kedua paham tersebut meyakini bahwa semua agama memiliki kesamaan di tingkat transenden dan berbeda pada tataran luarnya saja. Tuhan yang dituju oleh agama-agama tersebut adalah satu yaitu, "The Real". William C Smith juga memberikan penekanan pada "Yang Sakral" dan "Yang Profan" dalam rangka mencari makna agama yang sebenarnya" ${ }^{44}$.

Paham di atas menurut James A Keaten bukanlah pluralisme, melainkan relativisme ${ }^{45}$. Dikotomi antara Yang Sakral dan Profan juga tidak mencakup semua agama di dunia dan lebih terpaku pada agama Barat. Agama-agama kultur yang berpandangan universisme seperti Konghucu, Tao dan Shinto tidak termasuk dalam definisi

\footnotetext{
40 Ihsan Ali Fauzi, Ketika Agama, h. 5

${ }^{41}$ Nur Solikin, Agama dan, h. 132

42 Ibid.

${ }^{43}$ Yuangga Kurnia Yahya, Agama dan, h. 90

${ }^{44}$ Ibid, h. 24

45 James A Keaten dan Charles Soukup, Dialogue and, h. 176
} 
tersebut karena keyakinan mereka bahwa kehidupan religius berhubungan harmonis dengan tatanan alam dan manusia ${ }^{46}$.

Paham ini meyakini bahwa sebuah kebenaran (the Truth) seringkali memiliki banyak manifestasi. Namun definisi ini yang banyak dipahami orang sehingga sangat terganggu dan terusik ketika mendengar kata pluralisme. Nur Solikin memaparkan bahwa pluralisme di mata Islam adalah paham kemajemukan yang melihatnya sebagai suatu kenyataan yang bersifat positif dan sebagai keharusan bagi keselamatan umat manusia ${ }^{47}$.

Selain tipologi tripolar dari Alan Race di atas, terdapat model teologi antaragama lainnya. James A Keaten memberikan empat tipe, yaitu eksklusivisme, inklusivisme, relativisme dan pluralisme ${ }^{48}$. Paul F Knitter memperkenalkan model konservatif-Injil atau penggantian, Protestan arus-utama atau pemenuhan, model mutualis atau penerimaan dan model teosentris. Namun beberapa pengkaji agama di Indonesia memperkenalkan sikap baru yang disebut multikulturalisme.

Inti dari sikap ini adalah kesediaan menerima kelompok lain secara sama sebagai kesatuan, tanpa memperdulikan perbedaan budaya, etnik, gender, bahasa ataupun agama. Apabila pluralitas sekedar mempresentasikan adanya kemajemukan dan keragaman, multikulturalisme menerima dan menghargai berbagai sistem yang berbeda dan memberikan penegasan bahwa segala perbedaan tersebut adalah sama di ruang publik ${ }^{49}$. Dengan kata lain, multikulturalisme merupakan respons nyata kebijakan terhadap berbagai keragaman yang ada di ruang publik oleh negara.

Syamsu Rizal Panggabean menjelaskan bahwa keanekaragaman itu sendiri telah ada di dalam tubuh Islam, selain keanekaragaman di luar sana. Ia menjelaskan adanya dua arah multikulturalisme, yaitu internal dan eksternal. Secara internal, pluralisme identitas kultural keagamaan dalam masyarakat muslim

46 Mariassusai Dhawamony, Fenomenologi Agama, (Yogyakarta: Kanisius, 1995), h. 71

${ }^{47}$ Nur Solikin, Agama dan, h. 132

48 James A Keaten dan Charles Soukup, Dialogue and, h. 175-179

${ }^{49}$ Nur Solikin, Agama dan, h. 133 dan Yuangga Kurnia Yahya, Agama dan, h. 92 
adalah sebuah keniscayaan. Multikulturalisme internal ini mengisyaratkan kesediaan berdialog dan menerima kritik. Adapun multikulturalisme eksternal ditandai dengan pluralitas komunalkeagamaan. Sebagai bagian dari dunia yang majemuuk, umat Islam harus terus berinteraksi dengan umat dari agama-agama lain. Dengan interaksi ini umat Islam akan memperkaya dan diperkaya tradisi keagamaan lain dan sebaliknya. Dalam konteks Indonesia, multikulturalisme yang dibingkai dalam semboyan "Bhinneka Tunggal Ika" merupakan sebuah keharusan demi terwujudnya keharmonisan bersama ${ }^{50}$.

\section{Pendekatan Fenomenologi: Pendekatan Penuh Kesadaran}

Fenomenologi adalah sebuah pendekatan dalam ilmu sosial. Fenomenologi berasal dari bahasa Yunani "phainein" 'memperlihatkan' atau "phaenesthai" 'menyala, menunjukkan dirinya, muncul' yang kemudian dari akar kata ini menjadi kata "phainemenon" atau "phenomenon" 'sesuatu yang muncul, menerangi, menempatkan sesuatu dalam terang'. Dalam definisi sederhana, fenomenologi dianggap sebagai "kembali kepada benda itu sendiri" (back to the things

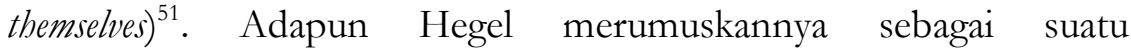
pengetahuan sebagaimana pengetahuan itu tampil atau hadir dalam kesadaran ("knowledge as it appears to consciousness")" ${ }^{52}$. Menurutnya, fenomenologi menunjukkan sebagaimana ia tampak, ilmu yang menggambarkan apa yang dipikirkan, dirasakan dan diketahui oleh seseorang dalam kesadarannya saat itu ${ }^{53}$ atau apa yang disebut sebagai immediate awareness dan experience ${ }^{54}$. Fokus pendekatan ini adalah sebuah upaya mengungkapkan "phenomenal consciousness"

\footnotetext{
dan, h. 92

${ }^{50}$ Nur Solikin, Agama dan, h. 138-139 dan Yuangga Kurnia Yahya, Agama

51 Rusli, Pendekatan Fenomenologi Dalam Studi Agama: Konsep, Kritik dan Aplikeasi, (Artikel dalam jurnal ISLAMICA, Vol. 2., No. 2, Maret 2008), h. 141 dan Heddy Shri Ahimsa-Putra, Fenomenologi Agama: Pendekatan Fenomenologi untuke Memahami Agama, (artikel dalam Jurnal Walisongo, Vol. 20, No. 2, November 2012), h. 276

52 Heddy Shri Ahimsa-Putra, Fenomenologi Agama, h. 273

${ }^{53}$ Rusli, Pendekatan Fenomenologi, h. 142

54 Heddy Shri Ahimsa-Putra, Fenomenologi Agama h. 274
} 
'kesadaran fenomenal' melalui ilmu pengetahuan dan filsafat, menuju ke "the absolute knowledge of the absolute"

Istilah ini akrab dengan nama Edmund Husserl sebagai pelopornya. Namun istilah fenomenologi sendiri telah digunakan dalam beberapa tulisan Immanuel Kant dan definisi lebih lanjut diberikan oleh Hegel $^{56}$. Pada awalnya Husserl berupaya menemukan dasar bagi sebuah filsafat yang membahas dan menelaah kenyataan. Dasar ini hanya dapat dicapai dalam bentuk kenyataan itu sendiri (things in themselves), sebagaimana ia menampakkan dirinya. Karenanya, Husserl mendefinisikan fenomenologi sebagai ilmu pengetahuan yang lekat dengan kesadaran ${ }^{57}$. Dengan struktur kesadaran tersebut memungkinkan kesadaran-kesadaran itu menunjuk kepada obyek lain di luarnya ${ }^{58}$. Husserl menjelaskan bahwa kesadaran ini meliputi dua aspek. Pertama, proses sadar itu sendiri (the process of being conscious). Kedua, yang menjadi objek dari kesadaran tersebut. ${ }^{59}$

Pendekatan dan studi ini membutuhkan refleksi tentang isi pikiran dengan mengesampingkan berbagai hal lain yang memungkinkan untuk mempengaruhi penampakan asli dari kenyataan atau fenomena tersebut atau natural attitude $e^{60}$. Metode yang digunakan menuru Husserl adalah "follows the nature of things to be investigated and not our prejudices or conceptions" 'mengikuti bentuk natural dari hal tersebut tanpa dibarengi dengan prasangka dan konsepsi awal'. Metode ini mengadopsi prosedur epoche dan eidetic vision dengan kajian terhadap beragam simbolik yang direspons oleh orang-orang sebagai nilai yang tidak terbatas ${ }^{61}$. Refleksi ini yang disebut oleh Husserl sebagai "reduksi fenomenologis"

55 Heddy Shri Ahimsa-Putra, Fenomenologi Agama, h. 274 dan Rusli, Pendekatan Fenomenologi, h. 142

56 Heddy Shri Ahimsa-Putra, Fenomenologi Agama..., 273 dan Rusli, Pendekatan Fenomenologi, h. 141

${ }^{57}$ Heddy Shri Ahimsa-Putra, Fenomenologi Agama, h. 274

${ }^{58}$ Rusli, Pendekatan Fenomenologi, h. 142

${ }^{59}$ Heddy Shri Ahimsa-Putra, Fenomenologi Agama, h. 274

${ }^{60}$ Rusli, Pendekatan Fenomenologi, h. 142 dan Fred Kersten, Phenomenological Method: Theory and Practice, (Dordrecht: Kluwer Academic Publishers, 1989), h. 30

61 Heddy Shri Ahimsa-Putra, Fenomenologi Agama, h. 275 dan Rusli, Pendekatan Fenomenologi, h. 145

62 Rusli, Pendekatan Fenomenologi, h. 142 
Ide terpenting yang dimunculkan Husserl adalah tentang deskripsi fenomenologis sebagai deskripsi, penggambaran dari segala sesuatu apa adanya. Hal tersebut akan dideskripsikan sebagaimana ia tampil dan hadir di hadapan manusia dalam cara tampilnya. Ide ini memiliki relevansi terhadap ilmu sosial budaya ${ }^{63}$. Kemudian Albert Schutz, murid Husserl memodifikasi pandangan ini ke dalam ranah sosiologi. Ia mengembangkan dasar konsep intersubyektivitas sebagai suatu hubungan timbal-balik perspektif, yang mencakup dua macam idealisasi, yaitu interchangability of view-points dan congruence of system of relevances. Idealisasi yang pertama adalah anggapan seorang bahwasanya ia dan orang lain akan mendapatkan pengalaman yang sama atas "dunia bersama" (common world). Adapun pada idealisasi yang kedua, masalah yang perlu dipahami adalah bagaimana si pelaku mendefinisikan situasi yang dihadapi. Dengan kedua idealisasi tersebut, interaksi sosial dalam kehidupan sehari-hari dapat berlangsung dengan lancar. Dalam interaksi tersebut, pelaku sadar atau tidak sering membuat sebuah "typification" "pemberian tipe atau $\operatorname{ciri}^{64}$.

Beberapa karakteristik dasar fenomenologi dapat dilihat dalam 5 poin. Pertama, watak deskriptif. Kedua, antireduksionisme. Ketiga, intensionalitas. Keempat, pengurungan (epoche). Kelima, Eidetic vision ${ }^{65}$. Selain itu beberapa hal di bawah menjadi landasan epistemologis pendekatan ini dalam fenomena sosial budaya:

1. Fenomenologi memandang manusia sebagai makhluk yang memiliki kesadaran.

2. Pengetahuan pada manusia ini berawal dari interaksi atau komunikasi di antara manusia, antara satu individu dengan individu lain.

3. Karena kesadaran tersebut lahir dari proses interaksi dan komunikasi, maka ia bersifat intersubyektif.

4. Perangkat pengetahuan ini menjadi pembimbing individu dalam mewujudkan perilaku-perilaku dan tindakantindakannya. Dengan demikian, perilaku dan tindakan

\footnotetext{
${ }^{63}$ Heddy Shri Ahimsa-Putra, Fenomenologi Agama, h. 277

64 Heddy Shri Ahimsa-Putra, Fenomenologi Agama, h. 279-280

${ }^{65}$ Rusli, Pendekatan Fenomenologi, h. 143
} 
individu tidak berdasar pada situasi yang obyektif, namun oleh kesadarannya terhadap hal tersebut.

5. Adanya typification atau pemberian tipe-tipe terhadap unsurunsur yang ada dalam kehidupan manusia.

6. Pengakuan bahwa kehidupan manusia merupakan kehidupan yang bermakna.

7. Dalam memahami gejala sosial menuntut pula pemahaman atas kerangka kesadaran yang digunakan untuk membangun perangkat pemaknaan tersebut.

8. Metode yang tepat dalam memahami gejala sosial adalah dengan mengetahui dan memahami "hakikat" dari gejala yang dipelajari tersebut ${ }^{66}$.

Memahami dalam konteks ini adalah mengetahui pandanganpandangan, pengetahuan, nilai-nilai, norma, aturan yang ada dalam suatu masyarakat atau yang dianut oleh individu. Setelah itu menetapkan relasinya dengan perilaku warga masyarakat, perilaku sebuah kolektivitas atau perilaku individu tertentu ${ }^{67}$.

Pendekatan ini memiliki dua unsur pokok yang tak terpisahkan. Unsur yang pertama adalah usaha untuk menunda prasangka dan ide atau konsepsi awal tentang sesuatu yang sedang diteliti atau yang dikenal dengan “epoche” 'pengurungan' (bracketing ) Epoche adalah pengurungan semua anggapan dan penilaian sebelumnya dan memposisikan diri terhadap obyek dengan setiap pengalaman konkret yang dialami oleh peneliti dan pelaku ${ }^{69}$. Inti dari epoche adalah keraguan, yaitu keraguan tentang natural attitude atau prasangka yang telah dimiliki sebelumnya ${ }^{70}$.

Unsur kedua adalah eidetic vision atau eidetic intuition. Eidetic vision berarti melihat ke dalam jantung makna (makna agama). Pada

${ }^{66}$ Heddy Shri Ahimsa-Putra, Fenomenologi Agama, h. 281-283

${ }^{67}$ Ibid, h. 285

${ }^{68}$ Joseph J. Kockelmans, Edmund Husserl's Phenomenology, (West Lafayette, Indiana: Purdue University Press, 1994), h. 43; Rusli, Pendekatan Fenomenologi....., 145 dan Darren Langdridge, Phenomenological Psychology: Theory, Research and Method, (Essex: Pearson Education Limited, 2007), h. 17

${ }^{69}$ Joseph J. Kockelmans, Edmund Husserl's, h. 43 dan Darren Langdridge, Phenomenological, h. 17

${ }^{70}$ Darren Langdridge, Phenomenological, h. 17 
unsur ini, peneliti melihat, mengenali secara komprehensif dan mendeskripsikan fenomena yang ditemui sebagai suatu kesatuan makna (unity of meaning). ${ }^{71}$

Dalam penerapan pendekatan fenomenologis, khususnya yang berkaitan dengan fenomena keagamaan, Prof. Dr. Heddy Shri Ahimsa-Putra, pakar antropologi, menetapkan beberapa prinsip etismetodologis yang perlu diperhatikan ${ }^{72}$. Pertama, tidak menggunakan kerangka pemikiran tertentu untuk menilai kebenaran pandangan subyek. Hal tersebut dikarenakan tugas peneliti bukanlah menilai atau menentukan kebenaran pandangan keagamaan yang diteliti, namun mendeskripsikannya sebaik mungkin melalui perspektif penganutnya. Kedua, pandangan keagamaan yang didapat juga tidak memerlukan penilaian. Dalam kacamata fenomenologi, semua "kesadaran" adalah "benar".

Ketiga, dalam melihat fenomena atau subyek, peneliti dapat dianalogikan sebagai "murid" yang ingin memahami pandangan keagamaan suatu individu atau komunitas dan bermaksud mendeskripsikannya sesuai pemahaman individu tersebut. Keempat, peneliti harus selalu mengingat bahwa tujuan utamanya adalah mengungkapkan pandangan, keyakinan atau kesadaran kolektif masyarakat terhadap suatu fenomena keagamaan. Karenanya, hendaknya peneliti menahan diri dari memberikan pendapat yang mungkin bertolak belakang dengan pandangan subyek. Konsepkonsep inilah yang akan dibawa dalam ranah komunikasi antaragama sebagai pendekatan awal dalam memahami konsepsi agama menurut kacamata penganutnya.

\section{E. Pendekatan Fenomenologi dalam Komunikasi Antaragama}

Para penggiat perdamaian menawarkan berbagai solusi untuk menjembatani hubungan antaragama. Di Nigeria, Imam Muhammad Asshafa dan Pastor James Wuye bekerja bersama membangun perdamaian antara Islam dan Kristen di Nigeria ${ }^{73}$. Kedua tokoh yang

71 Rusli, Pendekatan Fenomenologi, h. 145 dan Joseph J. Kockelmans, Edmund Husserl's, h. 43

${ }^{72}$ Heddy Shri Ahimsa-Putra, Fenomenologi Agama, h. 298-300

${ }^{73}$ Ihsan Ali Fauzi, Ketika Agama, h. 15 
dikenal dengan "The Imam and The Pastor" ini berjuang membina perdamaian antar kelompok yang bertikai setelah keduanya saling bermusuhan selama bertahun-tahun. Mohammad Abu Nimer juga menawarkan konsep bina-damai (peacebuilding) dan nirkekerasan (nonviolence) dari berbagai pemeluk agama ${ }^{74}$. Duncan Wielzen dan Ina Ter Avest mengajak para pakar untuk merumuskan pendidikan antaragama untuk semua kalangan (Interfaith Education for all). Mereka menjabarkan berbagai teori dan pengalaman praktik di lapangan terkait penanaman pendidikan antaragama sejak dini dengan mengambil studi kasus dari berbagai agama di berbagai belahan bumi $^{75}$. Selain yang disebutkan di atas masih banyak nama-nama yang giat membangun dialog antaragama di dunia.

Namun berbagai gerakan, teori dan praktik dialog antar agama yang digagas di atas tidak dapat berjalan lancar tanpa beberapa faktor pendukung. Young Yun Kim, seorang pakar komunikasi antarbudaya dan antaragama menyatakan bahwa salah satu faktor terpenting demi lancarnya berbagai gerakan dan konsep di atas adalah komunikasi $^{76}$. Komunikasi yang baik antar pemeluk agama dapat memuluskan konsep bina-damai, pendidikan antaragama dan lain sebagainya. Mengacu pada konsep Stella Ting-Toomey, proses komunikasi tersebut harus dimulai dengan saling membuka diri dalam menerima dan memahami kepercayaan dan ajaran yang dianut oleh pemeluk agama lain ${ }^{77}$. Pendekatan fenomenologi menawarkan salah satu solusi untuk memulai komunikasi antaragama demi menciptakan kedamaian dan meminimalisir kekerasan komunal dan kecurigaan antar pemeluk agama.

Unsur pokok pendekatan ini adalah epoche dan eidetic vision. Dengan epoche, pemeluk suatu agama dapat menghilangkan berbagai prasangka dan dugaan awal terkait label yang menempel pada pemeluk agama lain. Tidak akan ditemukan pemeluk agama Kristen yang menganggap Islam adalah agama kekerasan dan teroris, pemeluk

${ }^{74}$ Muhammad Abu Nimer, Conflict Resolution, Culture and Religion: Toward a training model of Interreligious Peacebuilding, (dalam Journal of Peace Research, Vol. 38, No. 6, November 2001), h. 685

75 Duncan Wielzen dan Ina Ter Avest, eds., Interfaith Education For All: Theoretical Perspectives and Best Practices for Transformative Action, (Rotterdam: Sense Publishers, 2017), h. 1

${ }^{76}$ Young Yun Kim, Communication and, h. 124

77 Stella Ting-Toomey, Communicating, h. 22-23 
agama Kristen yang melabeli pemeluk Hindu dan Budha agama tak bertuhan atau memiliki lebih dari satu Tuhan dan pemeluk agama Islam yang menganggap konsep ketuhanan agama lain bertentangan dengan sila ketuhanan Yang Maha Esa. Epoche mensyaratkan seorang pemeluk agama untuk melihat ajaran dan keyakinan agama lain dengan perspektif para pemeluknya, bukannya menempelkan label sesat dan salah sebelum mempelajari ajaran yang dianut.

Bila telah melewati fase epoche, maka pemeluk suatu agama dapat melihat nilai dan esensi dari agama lain atau eidetic vision. Pandangan ini adalah pandangan yang murni, tulus dan obyektif dan bukan pandangan yang telah terkontaminasi prasangka, "katanya" dan "biasanya". Pandangan ini melihat langsung ke jantung makna agama lain tanpa tertutupi aksi oknum-oknum dari penganut agama tersebut. penyataan Muhammad Abduh "al-Islaam mahjunbun bil Muslimiin" 'agama Islam tertutup oleh perbuatan orang-orang muslim' tidak akan berlaku. Pandangan ini serupa dengan konsep tawbiid dalam Islam di mana dalam syahadat dimulai dengan peniadaan Tuhan. Setelah mengakui tiada Tuhan yang disembah, barulah menetapkan satu Tuhan yang layak diimani dan diyakini. Setelah semua prasangka dan pengetahuan masa lampau terkait ajaran dan keyakinan suatu agama dihilangkan, pengetahuan seseorang akan kosong. Ketika kosong, ia akan mudah untuk menerima ajaran-ajaran yang diyakini oleh pemeluknya, bukan yang ia pelajari dari buku-buku atau dari selain pemeluknya.

Bila kedua syarat pendekatan fenomenologi tersebut telah terpenuhi, komunikasi dan dialog antaragama dalam masyarakat dapat berjalan lancar. Berbagai kegiatan dan ritual dan keagamaan yang dilaksanakan oleh suatu kelompok agama tidak akan menimbulkan kecurigaan bagi pihak lain. Mereka juga tidak akan saling menuduh, saling menyinggung dan saling tersinggung ketika kegiatan keagaaman suatu pemeluk agama harus menggunakan fasilitas umum dan melibatkan banyak pihak.

Ketika umat Islam menunaikan shalat berjama'ah atau sholat Ied misalnya, mereka memerlukan penggunaan pengeras suara demi terdengarnya suara adzan, suara imam saat sedang menunaikan shalat dan suara khatib saat berkhutbah. Khususnya pada dua hari raya umat Islam, Iedu'l Fitri dan Iedu'l Adha, umat Islam membutuhkan tempat ibadah dengan kapasitas yang cukup luas seperti lapangan, 
tempat parkir hingga ruas jalan raya karena hari besar tersebut hanya berlangsung satu tahun sekali. Bila hal tersebut telah diawali dengan epoche dan eidetic vision dari pemeluk agama lain dan dilanjutkan dengan dialog dan komunikasi yang baik antara kedua belah pihak, niscaya pembakaran Masjid di Tolikara, Papua dan kerusuhan di Tanjung Balai, Sumatera Utara tidak perlu terjadi.

"Peringatan 500 tahun Reformasi Gereja" memiliki arti yang penting bagi umat Kristiani. Suatu angka yang menunjukkan waktu tidak sedikit. Tanpa adanya reformasi gereja oleh Martin Luther King, gereja kemungkinan besar akan memaksakan ajaran mereka yang kaku dan otoriter. Menurut Professor Hans-Peter Grosshans dari Protestant Theology Department, University of Münster, Jerman, tanpa reformasi gereja tidak akan ditemukan terjemahan Alkitab ke dalam berbagai bahasa seperti saat ini, kekuasaan absolut Paus akan mencengkeram kehidupan umat Kristiani, tidak ada pendeta wanita, tidak diperbolehkan menggunakan nyanyian saat peribadatan, tidak ada akulturasi dan asimilasi ajaran Kristen dan budaya lokal dan kebebasan dalam berbagai hal merupakan sebuah kemustahilan ${ }^{78}$. Karenanya tidak mengejutkan bila umat Kristiani berbondongbondong menghadiri acara Kebaktian Kebangunan Rohani (KKR) oleh Pdt. Stephen Tong sebagai salah satu rangkaian peringatan tersebut dan menggunakan stadion Mandala Krida, Yogyakarta untuk pelaksanaannya. Namun karena ketiadaan sifat epoche dan eidetic vision dari beberapa pihak, acara tersebut justru mendapat penolakan dan dianggap sebagai suatu gerakan pemurtadan massal.

Begitu pula bila penganut agama lain memahami konsep Gereja sebagai "tubuh Yesus" dan Tuhan sebagai "kepalanya"79. Gereja juga tidak sebatas bangunan fisik, namun suatu persekutuan jemaat yang di sana mereka berkomunikasi, mendengarkan dan menerima firman Tuhan, di mana mereka menjawab panggilanNya dan sebagai jembatan antara Allah dan manusia ${ }^{80}$. Bila semua itu

78 Hans-Peter Grosshans, Preparing The Modern World: The Historical and Cultural Significance of the Reformation, dalam Wednesday Forum Center for Religious and Cross-cultural Studies, Gadjah Mada University, November 8, 2017 (private document)

79 Donald Dean Smeeton, Gereja; Gereja Tuhan Dalam Dunia, (Malang: Penerbit Gandum Mas, 1978), h. 62-66

80 Ari Krisna Widi Atmaja, Gereja Kristen Indonesia Di Babarsari, Yogyakarta. PhD Thesis, (Yogyakarta: Universitas Atma Jaya Yogyakarta, 2009), h. 11-12 
dipahami, tidak akan terjadi tuduhan kristenisasi yang dilanjutkan dengan demo dan penuntutan pemberhentian pembangunan Gereja St. Clara di Bekasi pada 2017 lalu, terlebih bila instansi pemerintah yang berwenang telah memberikan izin.

Salah satu konflik terhangat adalah pembubaran acara bakti sosial yang diselenggarakan oleh Gereja St. Paulus Pringgolayan, Banguntapan, Bantul oleh oknum pemeluk agama lain pada 29 Januari 2018 lalu. Kegiatan sosial yang merupakan rentetan acara peringatan catur windu atau 32 tahun berdirinya Gereja Katolik Santo Paulus tersebut dibubarkan karena dianggap sebagai sebuah kedok dari upaya kristenisasi di wilayah Bantul. Padahal dua hari sebelumnya, Bupati Bantul, Suharsono justru menghadiri gereja tersebut untuk peresmian gereja yang baru direnovasi.

Pembangunan patung Kongco Kwaan Sing Tee Koen di Klenteng Kwan Sing Bio, Tuban, Jawa Timur juga menjadi polemik. Kelompok agama mayoritas di Tuban merasa pembangunan patung setinggi 30 meter tersebut mencederai perasaan penduduk setempat. Beredar pula desas-desus bahwa patung tersebut adalah patung panglima perang Cina dan menjadi simbol kebangkitan gerakan komunisme di Indonesia. Padahal, menurut ketua umum Klenteng tersebut, patung yang diresmikan oleh Ketua MPR RI pada 17 Juli 2017 tersebut bukanlah simbol panglima perang, melainkan simbol Dewa Keadilan yang dipercaya umat Konghucu. Ada dua makna yang melekat dalam sosok tersebut, yaitu kesetiaan dan kebijaksanaan.

Beberapa contoh kasus benturan antaragama di atas menandakan pentingnya memahami ajaran dan ritual agama lain dengan murni dan tulus. Berbagai desas-desus "katanya" dan "dugaan" buruk dapat dihindari dengan pemahaman yang baik dan komunikasi yang komunikatif antar berbagai pihak. Berbagai kasus penistaan dan pelecehan agama juga tidak banyak terjadi bila pemeluk agama lain memahami apa "Yang Sakral" dan "Yang Profan" dalam ajaran agama lain dan tidak menjadikan semuanya sebagai bahan candaan dan sindiran.

Pemahaman ini bukan untuk menyamaratakan semua ajaran agama atau menganggap bahwa ajaran agama sendiri tidak penting. Usaha saling mengenal dan memahami ini merupakan jalan untuk 
membentuk komunikasi yang baik dan kekeluargaan yang kokoh atas dasar bangsa dan negara, bahkan kemanusiaan. Hal tersebut sesuai dengan konsep kekeluargaan yang dicanangkan oleh Hasan al-Banna. Ia memberikan tahapan persaudaraan dan persatuan sosial dalam tiga tahap; Ta'aaruf 'saling mengenal', Tafaahum 'saling memahami' dan Ta'aawun 'saling membantu'. Pertemuan ini untuk mensejajarkan hak agama di ruang publik atau pada level sosiologis. Adapun pada level teologis, klaim kebenaran dan keselamatan tiap agama adalah mutlak sesuai keyakinan agama tersebut. Dengan kata lain, semua agama adalah benar di mata para pemeluknya.

\section{F. Penutup}

Konsep epoche dan eidetic vision dalam pendekatan fenomenologi dapat menjadi tawaran solusi untuk memulai komunikasi dan dialog antaragama. Selama masih ada prasangka dan stereotyping pihak lain menggunakan perspektif agama masing-masing, maka dialog dan komunikasi tidak akan berlangsung komunikatif dan cenderung berjalan di tempat. Hal tersebut amat diperlukan di negara yang penuh dengan pluralitas budaya dan agama, bahkan cenderung multi-kultural seperti Indonesia ini. Berbagai memori kelam seperti kejadian di Poso, Ambon, Sampit hingga memori zaman penjajahan selalu menjadi perspektif baku dalam memandang ajaran dan keyakinan dari pemeluk agama lainnya. Kemajemukan dan keragaman di Indonesia yang sejatinya menjadi rahmat dan anugerah, justru berpotensi besar menimbulkan berbagai kekerasan komunal antar pemeluk agama.

Dengan pendekatan ini, diharapkan dalam pemeluk agama di Indonesia semakin lapang menyikapi perbedaan dan giat mempelajari sikap agama lain yang berlainan. Keterbukaan berbagai pihak untuk berbagi, memahami dan menerima masukan dapat memperkokoh jalinan kebangsaan yang telah terjalin selama ini. Bangsa ini tidak sedang berkompetisi dalam menentukan agama siapa yang paling benar dan agama siapa yang salah, namun tidak pula menyamaratakan kedudukan teologis semua agama. Bangsa ini hanya perlu menjaga keutuhan Negara Kesatuan Republik Indonesia (NKRI) dengan tidak membedakan yang sama dan tidak menyamakan yang berbeda. 


\section{Daftar Pustaka}

Ahimsa-Putra, Heddy Shri, Fenomenologi Agama: Pendekatan Fenomenologi untuk Memahami Agama. Paper in Walisongo Journal, Vol. 20, No. 2, November 2012.

Atmaja, Ari Krisna Widi, Gereja Kristen Indonesia Di Babarsari, Yogyakarta. PhD Thesis. Universitas Atma Jaya Yogyakarta, 2009.

Boase, Roger, ed., Islam and Global Dialogue: Religious Pluralism and the Pursuit of Peace. Hants, England: Ashgate Publishing Ltd, 2005.

Coward, Harold, Pluralisme Tantangan bagi Agama-Agama. Terj. Pluralism, Challenge to Worlds Religion. Yogyakarta: Kanisius, 1989.

Das, Shrimati and Ida Rohani, Culture as Competing Forces of Globalization, in International Seminar held by Intercultural Departmen, Faculty of Cultural Science, Gadjah Mada University, on October 23, 2017 (private document)

Dhawamony, Mariassusai, Fenomenologi Agama. Yogyakarta: Kanisius, 1995.

Fauzi, Ihsan Ali, ed. Ketika Agama Bawa Damai, Bukan Perang: Belajar dari "Imam dan Pastor". Jakarta: PUSAD Paramadina, 2017.

Grosshans, Hans-Peter, Preparing The Modern World: The Historical and Cultural Significance of the Reformation, on Wednesday Forum held by Center for Religious and Cross-cultural Studies, Gadjah Mada University, on November 8, 2017 (private document)

Hakiki, Kiki Muhamad, Politik Identitas Agama Lokal (Studi Kasus Aliran Kebatinan), Analisis, Volume XI, Nomor 1, Juni 2011.

Huntington, Samuel P. The Clash of Civilizations? In Foreign Affairs. New York: Summer 1993. Vol. 72, Iss: 3. 
Jenkins, Alan, The Social Theory of Claude Levi-Strauss. London: The Macmillan Press Ltd, 1979.

Keaten, James A and Charles Soukup, Dialogue and Religious Otherness: Toward a Model of Pluralistic Interfaith Dialogue. Paper in Journal of International and Intercultural Communication, Vol. 2: No. 2, 2009.

Kersten, Fred, Phenomenological Method: Theory and Practice. Dordrecht: Kluwer Academic Publishers, 1989.

Kim, Young Yun, Communication and Cross-Cultural Adaptation: An Integrative Theory Intercommunication. Clevedon: Multilingual Matters, Ltd, 1988.

Kockelmans, Joseph J, Edmund Husserl's Phenomenology. West Lafayette, Indiana: Purdue University Press, 1994.

Langdridge, Darren, Phenomenological Psychology: Theory, Research and Method. Essex: Pearson Education Limited, 2007.

Madjid, Nurcholis, Pluralitas Agama Kerukunan dalam Keragaman. Jakarta: Penerbit Kompas, 2001.

Nimer, Muhammad Abu, Conflict Resolution, Culture and Religion: Toward a training model of Interreligious Peacebuilding. Journal of Peace Research, Vol. 38, No. 6, 685-704, November 2001.

Rusli, Pendekatan Fenomenologi Dalam Studi Agama: Konsep, Kritik dan Aplikasi. Paper in journal ISLAMICA, Vol. 2., No. 2, March 2008.

Smeeton, Donald Dean, Gereja; Gereja Tuhan Dalam Dunia. Malang: Penerbit Gandum Mas, 1978.

Solikin, H. Nur, AR, Agama dan Problem Mondial. Yogyakarta: Pustaka Pelajar, 2013.

Strauss, Claude Levi, Race and History. Paris: Unesco, 1952.

Syalby, Abu Zayd, Taarïkhu'l Chadhaarah al-Islaamiyyah wa'l Fikru'l Islaamy. Kairo: Maktabah Wahbah, 2012.

Ting-Toomey, Stella, Communicating Across Cultures. New York: The Guilford Press, 1999. 
Wielzen, Duncan and Ina Ter Avest, eds. Interfaith Education For All: Theoretical Perspectives and Best Practices for Transformative Action. Rotterdam: Sense Publishers, 2017.

Yahya, Yuangga Kurnia. Upaya Bahasa Arab Dalam Menghadapi Era Globalisasi. In Konferensi Nasional Bahasa Arab (KONASBARA) III proceeding, Univ. Negeri Malang, 7 October 2017. - Agama dan Masyarakat. Jakarta: Nulisbuku.com, 2017. (selfpublishing)

\section{Sumber Berita Internet}

https://www.cnnindonesia.com/nasional/20180108111607-12267370/joshua-akan-dilaporkan-ke-polisi-karena-didugamenista-agama

http://www.globalmuslim.web.id/2011/02/inilah-kronologispelecehan-islam-oleh.html

https://www.tribunnews.com/nasional/2017/10/19/bareskrimperiksa-pelapor-eggi-sudjana-soal-dugaan-penistaanagama?page $=2$

http://bekasimedia.com/2016/10/11/di-bali-perempuan-kristendipenjara-14-bulan-karena-menghina-agama-hindu/

https://www.merdeka.com/peristiwa/habib-rizieq-kembalidipolisikan-soal-penistaan-agama.html

http://www.bbc.com/indonesia/trensosial-42601490 